\title{
COMMENTARY
}

\section{HMGB1 as a drug target in staphylococcal pneumonia}

Mitchell P Fink

See related research by Achouiti et al., http://ccforum.com/content/17/6/R296

\begin{abstract}
High mobility group box (HMGB) 1 is a small DNA-binding protein. In the nucleus, HMGB1 plays a role in gene expression and DNA replication. When it is released or secreted into the extracellular milieu, HMGB1 functions as a pro-inflammatory cytokine-like mediator. Recently reported data support the view that treatment with a neutralizing anti-HMGB1 antibody ameliorated pulmonary damage in a murine model of pneumonia caused by a pathogenic strain of Staphylococcus aureus. These findings suggest that HMGB1 may be an important drug target as scientists, clinical investigators and pharmaceutical companies seek to develop better agents for the treatment of staphylococcal pneumonia. Unfortunately, however, encouraging results from murine models of human disease often fail to translate into positive findings in clinical trials. Thus, before moving from pre-clinical into clinical studies, it may be prudent to validate and extend the recent experimental findings by carrying out additional studies, using a large animal model of pneumonia.
\end{abstract}

In a recent article in Critical Care, Achouiti and co-workers [1] from the Academic Medical Center in Amsterdam explored the role of high mobility group box (HMGB)1 in an animal model of pneumonia caused by a methicillin-resistant, highly pathogenic strain of Staphylococcus aureus. In order to better understand the implications of these findings, it is useful to briefly review the 'HMGB1 as inflammatory mediator' story.

HMGB1 was originally identified by Shooter and colleagues [2] as a relatively small, highly charged non-

Correspondence: mfink@mednet.ucla.edu

Departments of Surgery and Anesthesiology, David Geffen School of

Medicine at the University of California Los Angeles, Los Angeles, CA 90095, USA histone DNA-binding protein. About 25 years later, Wang and colleagues [3] identified HMGB1 as a late-acting mediator of lipopolysaccharide-induced lethality in mice. This important paper opened up a fresh avenue of research in immunology, one that led to the recognition that certain endogenous molecules, which can be passively released by stressed or necrotic cells or, in some cases, actively secreted by immunostimulated macrophages and certain other cell types, are capable of activating the innate immune system and initiating or propagating inflammation. These molecules are now collectively referred to as 'damage-associated molecular patterns' (DAMPs). In addition to HMGB1, other DAMPs include uric acid, heat shock proteins, adenosine triphosphate, and partially degraded forms of hyaluronic acid [4].

HMGB1 is a multifunctional protein. In the nucleus, it participates in DNA replication and the regulation of gene expression [5]. When it is released or secreted into the extracellular milieu, HMGB1 can act as a chemokine (that is, a chemoattractant for motile leukocytes) or a cytokine (that is, an immune system mediator) to promote the secretion of other cytokines, such as tumor necrosis factor, IL-1, and IL-6, by macrophages and other cell types. Whether extracellular HMGB1 acts as a chemokine, cytokine or neither depends upon the redox state of three critical cysteine residues (C23, C45 and C106) in the protein [6,7]. In order for HMGB1 to function as a chemokine, the thiol moieties in all three of these cysteine residues must exist in their fully reduced form. In order to function as a cytokine, two of the cysteine residues, C23 and C45, must form a disulfide bond, whereas the third cysteine residue, C106, must remain fully reduced. If the cysteine residues are fully oxidized to the sulfonate form, then both the chemokine and cytokine functions are abrogated. In its role as a cytokine, HMGB1-dependent signaling is initiated primarily by activation of Toll-like receptor (TLR) 4 and the receptor for advanced glycation endproducts (RAGE). In its role as a chemokine, HMGB1 forms a heterocomplex
C Biomed Central

(c) 2014 Fink; licensee BioMed Central Ltd. The licensee has exclusive rights to distribute this article, in any medium, for 12 months following its publication. After this time, the article is available under the terms of the Creative Commons Attribution License (http://creativecommons.org/licenses/by/4.0), which permits unrestricted use, distribution, and reproduction in any medium, provided the original work is properly cited. 
with the chemokine CXCL12 and initiates signaling via activation of the receptor CXCR4 [8].

Abundant evidence supports the view that HMGB1 is an important pathological mediator in animal models of several human diseases, including sepsis [9], hemorrhagic shock [10], and acute respiratory distress syndrome (ARDS) [11]. At present, ironclad evidence that HMGB1 is an important mediator of disease in humans is still lacking, although elevated circulating levels of HMGB1 have been detected in patients with sepsis [12], ARDS [13] or rheumatoid arthritis [14] and high levels of HMGB1 have been found in samples of synovial fluid from patients with rheumatoid arthritis [15].

Achouiti and colleagues [1] employed a murine model of sublethal pneumonia caused by a virulent strain of methicillin-resistant $S$. aureus (MRSA). Using wild-type mice as well as TLR4 and RAGE 'knock-out' (KO) mice, Achouiti and colleagues showed that $S$. aureus pneumonia was associated with HMGB1 release into bronchoalveolar lavage fluid. Treatment with a neutralizing anti-HMGB1 antibody ameliorated pulmonary damage. RAGE KO mice were partially protected from lung damage caused by S. aureus pneumonia, whereas TLR4 KO mice were not protected at all.

The data obtained by Achouiti and colleagues suggest that HMGB1 might be a viable drug target in patients with pneumonia caused by $S$. aureus, but the study conducted by Achouiti and colleagues has some limitations. First, the authors studied the role of HMGB1 in a S. aureus pneumonia model in the absence of appropriate antimicrobial chemotherapy. It is impossible to know whether administration of an effective antibiotic would have affected the results. Second, the mice were treated with the neutralizing anti-HMGB1 antibody (or the control antibody) prior to the onset of infection. In the clinical setting, treatment almost always would start after the onset of infection. Third, concerns have been raised about the predictive utility of murine models of sepsis [16]. These concerns stem from recent data showing that changes in gene expression in acutely endotoxemic mice are quite distinct from those observed in acutely endotoxemic human volunteers [17]. Furthermore, most studies using mice are conducted with the animals maintained at 'room temperature' $\left(20\right.$ to $\left.23^{\circ} \mathrm{C}\right)$. Housing laboratory mice under more physiological conditions (for the animals) might lead to results that are more applicable to the clinical situation [18]. Carrying out studies using a clinically relevant large animal model of MRSA pneumonia, such as the one described by Rehberg and colleagues [19], might be another way to validate the findings obtained in mice.

\section{Conclusion}

Staphylococcal pneumonia is an important clinical problem $[20,21]$. There clearly is a pressing, unmet clinical need for improved therapeutics for staphylococcal (particularly MRSA) pneumonia. Developing drugs that target HMGB1 may be one way to tackle this problem, although moving from the encouraging findings reported by Achouiti and co-workers to the registration of a new medicine will be an arduous task.

\section{Abbreviations}

ARDS: Acute respiratory distress syndrome; DAMP: Damage-associated molecular pattern; HMGB: High mobility group box; IL: Interleukin; KO: Knock-out; MRSA: Methicillin-resistant S. aureus; RAGE: Receptor for advanced glycation endproducts; TLR: Toll-like receptor.

\section{Competing interests}

The authors declare that they have no competing interests.

\section{Published: 31 Mar 2014}

\section{References}

1. Achouiti A, van der Meer AJ, Florquin S, Yang H, Tracey KJ, Vant Veer C, De Vos AF, Van der Poll T: High-mobility group box 1 and the receptor for advanced glycation end products contribute to lung injury during Staphylococcus aureus pneumonia. Crit Care 2013, 17:R296.

2. Shooter KV, Goodwin GH, Johns EW: Interactions of a purified non-histone chromosomal protein with DNA and histone. Eur J Biochem 1974, 47:263-270

3. Wang $\mathrm{H}$, Bloom $\mathrm{O}$, Zhang $\mathrm{M}$, Vishnubhakat $\mathrm{M}$, Ombrellino $\mathrm{M}$, Che J, Frazier A, Yang H, Ivanova S, Borovikova L, Manogue KR, Faist E, Abraham E, Andersson J, Andersson U, Molina PE, Abumrad NN, Sama A, Tracey KJ: HMG-1 as a late mediator of endotoxin lethality in mice. Science 1999, 285:248-251.

4. Rubartelli A, Lotze MT: Inside, outside, upside down: damage-associated molecular-pattern molecules (DAMPs) and redox. Trends Immunol 2007, 28:429-436.

5. Lotze MT, Tracey KJ: High-mobility group box 1 protein (HMGB1): nuclear weapon in the immune arsenal. Nat Rev Immunol 2005, 5:331-342.

6. Venereau E, Casalgrandi M, Schiraldi M, Antoine DJ, Cattaneo A, De Marchis F, Liu J, Antonelli A, Preti A, Raeli L, Shams SS, Yang H, Varani L, Andersson U, Tracey KJ, Bachi A, Uguccioni M, Bianchi ME: Mutually exclusive redox forms of HMGB1 promote cell recruitment or proinflammatory cytokine release. J Exp Med 2012, 209:1519-1528.

7. Yang $H$, Lundbäck P, Ottosson L, Erlandsson-Harris $H$, Venereau E, Bianchi ME, Al-Abed Y, Andersson U, Tracey KJ, Antoine DJ: Redox modification of cysteine residues regulates the cytokine activity of high mobility group box-1 (HMGB1). Mol Med 2012, 18:250-259.

8. Schiraldi M, Raucci A, Muñoz LM, Livoti E, Celona B, Venereau E, Apuzzo T, De Marchis F, Pedotti M, Bachi A, Thelen M, Varani L, Mellado M, Proudfoot A, Bianchi ME, Uguccioni M: HMGB1 promotes recruitment of inflammatory cells to damaged tissues by forming a complex with CXCL12 and signaling via CXCR4. J Exp Med 2012, 209:551-563.

9. Yang H, Ochani M, Li J, Qiang X, Tanovic M, Harris HE, Susarla SM, Ulloa L, Wang H, DiRaimo R, Czura CJ, Wang H, Roth J, Warren HS, Fink MP, Fenton MJ, Andersson U, Tracey KJ: Reversing established sepsis with antagonists of endogenous high-mobility group box 1. Proc Natl Acad Sci U S A 2004, 101:296-301.

10. Yang R, Harada T, Mollen KP, Prince JM, Levy RM, Englert JA, GallowitschPuerta M, Yang L, Yang H, Tracey KJ, Harbrecht BG, Billiar TR, Fink MP: Anti-HMGB1 neutralizing antibody ameliorates gut barrier dysfunction and improves survival after hemorrhagic shock. Mol Med 2006, 12:105-114.

11. Abraham E, Arcaroli J, Carmody A, Wang H, Tracey KJ: HMG-1 as a mediator of acute lung inflammation. J Immunol 2000, 165:2950-2954.

12. Fink MP: Bench-to-bedside review: High-mobility group box 1 and critical illness. Crit Care 2007, 11:229.

13. Ueno H, Matsuda T, Hashimoto S, Amaya F, Kitamura Y, Tanaka M, Kobayashi A, Maruyama I, Yamada S, Hasegawa N, Soejima J, Koh H, Ishizaka A: Contributions of high mobility group box protein in experimental and clinical acute lung injury. Am J Respir Crit Care Med 2004, 170:1310-1316.

14. Goldstein RS, Bruchfeld A, Yang L, Qureshi AR, Gallowitsch-Puerta M, Patel NB, Huston BJ, Chavan S, Rosas-Ballina M, Gregersen PK, Czura CJ, Sloan RP, 
Sama AE, Tracey KJ: Cholinergic anti-inflammatory pathway activity and High mobility group box-1 (HMGB1) serum levels in patients with rheumatoid arthritis. Mol Med 2007, 13:210-215.

15. Taniguchi N, Kawahara K, Yone K, Hashiguchi T, Yamakuchi M, Goto M, Inoue K, Yamada S, ljiri K, Matsunaga S, Nakajima T, Komiya S, Maruyama I: High mobility group box chromosomal protein 1 plays a role in the pathogenesis of rheumatoid arthritis as a novel cytokine. Arthritis Rheum 2003, 48:971-981.

16. Fink MP: Animal models of sepsis. Virulence 2013, 5:143-153.

17. Seok J, Warren HS, Cuenca AG, Mindrinos MN, Baker HV, Xu W, Richards DR, McDonald-Smith GP, Gao H, Hennessy L, Finnerty CC, López CM, Honari S, Moore EE, Minei JP, Cuschieri J, Bankey PE, Johnson JL, Sperry J, Nathens AB, Billiar TR, West MA, Jeschke MG, Klein MB, Gamelli RL, Gibran NS, Brownstein BH, Miller-Graziano C, Calvano SE, Mason PH, et al: Genomic responses in mouse models poorly mimic human inflammatory diseases. Proc Natl Acad Sci U S A 2013, 110:3507-3512.

18. Karp CL: Unstressing intemperate models: how cold stress undermines mouse modeling. J Exp Med 2012, 209:1069-1074.

19. Rehberg S, Yamamoto Y, Sousse L, Bartha E, Jonkam C, Hasselbach AK, Traber LD, Cox RA, Westphal M, Enkhbaatar P, Traber DL: Selective V(1a) agonism attenuates vascular dysfunction and fluid accumulation in ovine severe sepsis. Am J Physiol Heart Circ Physiol 2012, 303:H1245-H1254.

20. Moran GJ, Krishnadasan A, Gorwitz RJ, Fosheim GE, Albrecht V, Limbago B, Talan DA, EMERGEncy ID NET Study Group: Prevalence of methicillinresistant staphylococcus aureus as an etiology of community-acquired pneumonia. Clin Infect Dis 2012, 54:1126-1133.

21. Tadros M, Williams V, Coleman BL, McGeer AJ, Haider S, Lee C, lacovides H, Rubinstein E, John M, Johnston L, McNeil S, Katz K, Laffin N, Suh KN, Powis J, Smith S, Taylor G, Watt C, Simor AE: Epidemiology and outcome of pneumonia caused by methicillin-resistant Staphylococcus aureus (MRSA) in Canadian hospitals. PLoS One 2013, 8:e75171.

\section{$10.1186 /$ cc13810}

Cite this article as: Fink: HMGB1 as a drug target in staphylococcal pneumonia. Critical Care 2014, 18:131 